\title{
Translating Latin Poetry and the Interaction between Cultures
}

\author{
Magda El-Nowieemy \\ Professor of Greco-Roman Studies \\ Faculty of Arts- Alexandria University
}

As there has been a growing interest, in recent years, in translation activities and translation studies ${ }^{1}$, I would like to start by invoking an invitation to translation presented by the Roman writer Pliny the younger ${ }^{2}$ (61-112 C.E), in one of his letters to a friend ${ }^{3}$, advising him to spend his prolonged holiday, practicing the act of translation, as being the most useful exercise. Pliny suggests to his friend to translate Greek into Latin and Latin into Greek. He explains to him the benefits that could be gained through the act of translation in the following points:

1- Translation develops a precision and richness of vocabulary.

2- It develops a wide range of metaphor and power of exposition.

3- Imitation of the best models leads to a like quality of the original composition.

4- Any point that might be overlooked by a reader, cannot escape the eye of a translator.

5- All what precedes cultivates perception and critical sense.

The same reasoning of Pliny could also be extended to different cultures. It is worth mentioning that translating Greek and Latin texts has currently been gaining ground all over the world ${ }^{4}$; hence we can add an important point to what Pliny states concerning the benefits which might be gained through the act of translation. This additional benefit is the interaction between the culture of the original text and that of the translated 
$=$ Translating Latin Poetry and the Interaction between Cultures

text, the culture of the writer, and that of the translator. Translation is a sort of interpretative activity, through the rewriting of an original text ${ }^{5}$.

To ensure the dialogue of cultures, gained through translation, on equal terms, we have to go outside the text under translation, from time to time, to supply a piece of information, or to investigate relations of the text in our hands to its cultural context ${ }^{6}$. It is significant here, I should say, to quote a statement from Lorna Hardwick's illuminating study on Translating Words, Translating Cultures, as it has a direct bearing on my argument: "Translation is a movement which takes place not only across languages, but across time, place, beliefs and cultures. A translator's aim to communicate the nobility of Homer or the sublimity of Vergil is not a matter of simple lexical transfer but of cultural shaping and interpretation"7.

In the case of translating Roman poetry, in particular, another level of interaction is exemplified, that is the interaction of cultures within the original text itself, which needs to be transferred to the translated one.

In order to pave the way for my argument, let me start by saying that the Romans in the classical period were fighting for a literary location on ground already occupied by others before them.

As always the case, cultures shift their positions. The center of culture shifted from Athens to Alexandria in $3^{\text {rd }}$ Century B.C., and then Rome became the successor of these two centers in $1^{\text {st }}$ Century B.C. ${ }^{8}$, that is why Roman literature was receptive to the Greek and Alexandrian traditions. In the mind of any Roman poet, the three cultures co-existed. The Romans ever kept in their thought that the centers of culture were Athens and Alexandria, so their only literary models were Greek and Alexandrian. From this point did the Greco-Roman and Alexandrian-Roman interaction start. Hence, Greek and Alexandrian literatures retained longer-term identities through Roman literature ${ }^{9}$, and through translating the texts of that literature. As widely agreed, without these two elements Roman literature would have been completely different. 


\section{Magda El-Nowieemy}

There was an irresistible tendency among many great Roman poets to base their art on the past literature ${ }^{10}$. In the process of making their own texts, the Roman poets consulted various versions freely. Since the Roman was the receptor culture, Roman poetry is a fertile field for exploring interaction between cultures. Any Latinist could not help the temptation of tracing such Greco-Alexandrian interaction in Latin literature.

To gain a better understanding of my words let us see them in context. In determining the scope of this paper, I would restrict my selection and narrow my focus to one representative poem. This poem in question here is the first poem of the third book of Propertius ${ }^{11}$ (c. 54-16 B.C.), which is considered a programmatic poem. It is a significant poem to translate. To understand its significance is very interesting.

My present concern is mainly confined to the poet's vision of interaction between Alexandria, Greece and Rome. We should ask what in fact this poetical interaction may tell us in the process of translation.

In the very beginning of the poem, Propertius feels indebted to Alexandrian literary models. He invokes the ghosts of Callimachus and Philitas as being their successor:

Callimachi Manes et Coi sacra Philitae, in vestrum, quaeso, me sinite ire nemus.

Primus ego ingredior puro de fonte sacerdos

Itala per Graios orgia ferre choros.

Dicite, quo partier Carmen tenuastis in antro quove pede ingressi? Quamve bibistis aquam?

(Propertius, 3.1. 1-6)

"O ghosts of Callimachus and sacred rites of Coan Philitas, I ask you to allow me to come into your grove. I am the first to enter, a priest from a pure spring, bringing Italian orgies through Greek dances. Tell me, in what cave did you together spin the delicate thread of your song? With what foot 10 
$=$ Translating Latin Poetry and the Interaction between Cultures

do you enter? Or what water do you drink?"

Propertius, here, is looking forward to being accepted by the two great Alexandrian poets to write the sort of poetry they do. It does not escape the notice of the reader/translator that in 3.1, Propertius is inspired, like Callimachus, on mount Helicon ${ }^{12}$, and that he adheres to the Callimachean principles proclaimed in his much-debated prologue to the Aetia, and in the Hymn to Apollo ${ }^{13}$. Propertius' relations to the Alexandrian poets are too large a subject for the present study, and I have already treated them in two previous studies ${ }^{14}$.

To refer several times to the third-Century Alexandrian poets, Callimachus and Philitas as Propertius' predecessors in love-elegy, is suggestive. But as far as we can judge from the surviving examples, there is no indication that Callimachus and Philitas wrote subjective love-elegies of the Roman type. The Alexandrians wrote objective narrative elegies about mythological lovers, and amatory epigrams about their own experiences ${ }^{15}$. Propertius, and the other Roman elegists, wrote series of personal loveelegies to one mistress. So the Romans did not take over love-elegy as a ready-made genre, and were not second rate imitators. They reacted to, and interacted with that Alexandrian genre.

So long as Propertius claims more than once that Callimachus and Philitas were his predecessors in love-elegy ${ }^{16}$, this claim may invite direct comparison with the two Alexandrian poets.

Propertius was a self-confident and a self-conscious poet, very much aware of his workmanship, of his poetic technique, and of his role as an innovator. In spite of his pride of his genius, and instead of priding himself on his creative power, and claiming originality due to him, he prefers to be in the shade of the Greeks and Alexandrians. It is tempting to ask why he preferred such a thing.

I think that Propertius in 3.1 is adopting the traditional situation of Latin poets who present themselves as being "the first Roman" to follow a 


\section{Magda El-Nowieemy}

certain Greek model ${ }^{17}$. The "primus ego" motif, or the like, reflects the traditional Roman poets' boast on adapting Greek genres. And because Latin literature was receptive to Greek and Alexandrian traditions, it was very important for a Roman poet to be Roman Homer, Roman Hesiod, Roman Alcaeus, Roman Theocritus, Roman Philitas, and Roman Callimachus. There is sufficient reason, I suppose, to assume that there was an irresistible tendency among many great Roman poets to base their art on the past literature: classical Greek and Alexandrian. They were enthusiastic for their models, liked to be following in their footsteps, and they proudly proclaimed that.

Propertius worked within Greek and Alexandrian traditions, transplanted to Rome, but he fused them with personal experience as a Roman love-poet. His talk about Callimachus and Philitas was a sort of literary propaganda. Even if he was not a genuine Callimachus or a genuine Philitas, his invocation to them was a subtle way to escape imperial pressure, or namely that is how he responded to Maecenas, rejecting his demand to write epic. This is Propertius' politics of interaction between cultures. Propertius seems to have escaped from Roman pressure into Greek and Alexandrian $\operatorname{art}^{18}$, from Roman individualism to Greco-Roman and Alexandrian-Roman interaction.

Let us turn now to the second main point in Propertius poem 3.1, which is the immortal fame that will be his:

At mihi quod vivo detraxerit invida turba,

post obitum dulpici faenore reddet honos;

Omnia post obitum fingit maiora vetustas:

Maius ab exsequiis nomen in ora venit.

(Propertius, 3.1.21-24)

"But what the envious crowd disallows me while alive, after my death Honor will repay with double interest. Time makes all things greater after $\Lambda \vee$ 
death: from funeral a name becomes greater on (people's) lips."

Propertius says that the praise and fame that may be denied to him during his lifetime await him after death, on equal level with Homer:

Nec non ill etui casus memorator Homerus

posteritate suum crescere sensit opus;

meque inter seros laudabit Roma nepotes:

illum post cineresauguror ipse diem.

(Propertius, 3.1, 33-36)

"And Homer, that reminder of your (i.e. Troy's) fate has felt his own work grow with posterity. Rome also will praise me among its late generations: I myself predict that day (to come) after (becoming) ashes."

How fascinating to see the elegiac poet who prided himself on writing love-poetry, and who professed once and again that his talents were unfit to epic ${ }^{19}$, turning now, deliberately and unexpectedly, to claim for himself the honorable status of the greatest Greek epic poet, Homer! Here is a fusion of Roman pride, and Greek art, Roman love-elegy and Greek epic. These are challenging claims on Propertius' $\operatorname{side}^{20}$.

As we have seen, Propertius in 3.1 establishes a relation with Greek literature of the past, and with Alexandrian literature from which the Roman poets of his age drew, to a great extent, their literary forms, subjects and technique. Propertius was Roman in heart, Alexandrian in thought and sometimes in technique, claimant to a status equal to that of the most remarkable Greek epic-poet.

Propertius, a most daring Roman poet, with special sense of humor, apparent playfulness, deep irony, profound complexity and subtle technique, succeeds in presenting the interaction between Roman individualism, Greek greatness and thought, and some Alexandrian technique, involving his own personality as a Roman lover-poet. All this interaction is reflected in the mirror of translation.

To conclude, since translation, as generally agreed, is not a matter of 
dictionaries and grammars, the line-for-line, and word-for-word translation may misjudge, or ruin the spirit of the original text, or say, the real spirit of the original text may be lost completely ${ }^{21}$. Hence, I argue that a Latin poem cannot be translated in isolation, as long as the Romans transferred their predecessors' texts into their own, both explicitly and implicitly.

It is necessary, in the process of translating Latin poetry, to achieve a comparative perspective, or say cross-cultural perspective, in which the significant lines of connection and distinction, among the various poets, are drawn. Therefore the technique of translating as such could be employed productively to read classical Roman poetry from a multicultural perspective: ancient Greek, Alexandrian, and classical Latin. The Art of translation in this way is a contribution to cultural studies in general, which is, to my mind, a central and productive function of the act of translation. 
Translating Latin Poetry and the Interaction between Cultures

\section{Notas}

1 - See Andre Lefevere, ed., Translation/History/Culture. A Sourcebook, Routledge, 1992, p. xi: "The growth of Translation Studies as a separate discipline is a success story of the 1980s. The subject has developed in many parts of the world and is clearly destined to continue developing well into the $21^{\text {st }}$ century". Ibid. p. xiv: "We are finally beginning to realize that translation deserves to occupy a much more central position in cultural history than the one to which it is currently relegated".

2 - Pliny, Epistulae, VII. ix.

3 - This friend was Fuscus Salinator.

4 - For the views held by both Ezra Pound and T. S. Eliot about the importance of the classics in translation, see: J. P. Sullivan, "Critical Continuity and Contemporary innovation", in Irene De Jong, et al. (eds.), Modern Critical Theory and Classical Literature, E. J. Brill, 1994, pp. 11f.

5 - Lefevere (1992) p. xi:"Translation is of course a rewriting of an original text. All rewritings, whatever their intention, reflect a certain ideology and a poetics and as such manipulate literature to function in a given society in a given way...Rewritings can introduce new concepts, new genres, new devices, and the history of translation is the history also of literary innovation, of the shaping power of one culture upon another".

6 - Lefevere (1992) p. 8, argues that in order to make a foreign work of literature acceptable to the receiving culture, translators will often adapt it to the poetics of that receiving culture.

7 - Lorna Hardwick, Translating Words, Translating Cultures, Duckworth, 2000, p. 17.

8 - For a good argument, see K. Quinn, Texts and Contexts, The Roman Writers and their Audience, Routlege and Kegan Paul, 1979, pp. 15 ff., who rightly reminds us that literature did not begin in Athens; it began with Homer on the Mediterranean seaboard of what we now call Turkey, perhaps in the eighth century B.C.; but it was Athens which became in the fifth and fourth centuries the centre of the classical age of Greek literature, the home of the drama, the home of philosophy and intellectual inquiry, the centre to which others journeyed to listen and to learn, or to make their reputations as teachers.

9 - Propertius' work, for one, contains a dense network of references to ancient and contemporary literature, see: A. Dihle, Greek and Latin Literature of the Roman Empire, Routledge, 1994, pp. 38 ff.

10 - It is convenient to refer here to the statement of Virginia Woolf quoted in D. Porter, "The Thread of Ariadne: The Classics and the Twentieth Century", CJ 79 (1984) 347: "what draws us back and back to the Greeks is the fact that the stable, the permanent, the original human being is to be found there."

11 - In Arkins' words: "For such highly explicit acknowledgment, for direct admission of the poetic authority of Callimachus, we must turn to Propertius." See: B. Arkins, "The Freedom of Influence: Callimachus and Latin Poetry", Latomus XLVII (1988) p. 289. Cf. R.Thomas, "Callimachus, the Victoria Berenices, and Roman Poetry", CQ 83 (1983) pp. $101 \mathrm{ff}$. For Propertius as being the faithful Callimachean, see: C. W. Macleod, "Propertius 4.1", in: Collected Essays, ed. by Collin Macleod, Oxford, 1983, pp. 202 ff.

12 - In 3.1. 17 f., Propertius says: 
Sed, quod pace legas, opus hoc de monte sororum detulit intacta pagina nostra via.

"But this work which you may read in peace-time, my page has brought down from the mountain of the sisters (Muses) by untrodden path."

13 - For Callimachus' surviving statements about poetry, see: Aetia, Prologue 1-28; Hymn to Apollo, 105-114. For more details about Callimachus' literary theory, see: T. M. Klein, "The Role of Callimachus in the Development of the Concept of the Counter-Genre", Latomus XXXIII (1974) pp. 221 ff.; M. J. Edwards, "Callimachus, Roman Poetry and the Impotence of Song", Latomus LIII (1994) pp. 807ff.

14 - See: Magda El-Nowieemy, "Alexandrian Influences in Propertius' Poetry" (in Arabic), in: The Ancient Library of Alexandria and its Role in Africa, Institute for African Studies, Cairo, 2005, pp. 115 ff.; "Callimachus and Roman Poetry" (in Arabic), Bulletin of the Faculty of Arts, Alexandria University, vol. 58, (2008) pp. $535 \mathrm{ff}$.

15 - For the ways elegy was used in Hellenistic times, see: A. Cameron, Callimachus and his Critics, Princeton, 1995, pp. 149-152.

16 - Elsewhere in his poems, Propertius puts himself with Callimachus and Philitas: In 3.3, he says that the Muse moistens his mouth with the water of Philitas. In 3.9, he says that it is enough for him to be accepted among the books of Callimachus and to sing in the manner of Philitas. Cf. Prop. 2.1, 2.13, 4.1, 4.6. Luck calls Prpertius "the legitimate successor of Callimachus and Philetas, he is poeta doctus- scholar and critic as well as poet", see: G. Luck, The Latin Love-Elegy, London, 1959, p. 124. For the Roman Callimachus, see: J. P. Sullivan, Propertius: A Critical Introduction, Cambridge, 1976, pp. $107 \mathrm{ff}$.

17 - Latin poets were given to boasting their priority in adapting Greek genres; cf. Lucretius, De Rerum Natura, 1. 926-930; Vergilius, Georgica, 2. 174- 176; Horatius, Carmina, 3.30. 12-14.

18 - See: Nancy Wiggers, "Reconsiderations of Propertius II.1", CJ 72 (1977) pp. 334 ff.

19 - For details, see: Magda El-Nowieemy, "Catullus 68 and the Tradition of the Recusatio Poems", in: Alexandrian Studies II in Honour of Mostafa El Abbadi, Société D Archéolgie D’Alexandrie, Bulletin 46 (2001) pp. 255 ff.

20 - For Propertius' equation of elegy and epic, see Wiggers (1977) pp. $338 \mathrm{ff}$.

21 - See Hardwick (2000) p. 17: "Clearly, then, there are several levels of activity and of response to the processes involved in translation. It is not possible simply to translate one word by its apparent verbal equivalent; the letter is not enough. There is a complex web of tone, register and meaning which draws on the effects of vocabulary, sound, rhythm and metre in both the source text and the translation". 